\title{
Youth Representation within the World's Parliaments
}

\author{
Alexandra Barbus, $\mathrm{PhD}$ Candidate \\ Babes Bolyai University, Cluj Napoca, Romania
}

\begin{abstract}
Youth political participation has been for many years now a major topic across scholars: how often they engage, what are the main forms of political participation and why is the youth segment absent when it comes to civic engagement as compared to the older generations. One of the main explanations for the apathy of the youth segment when it comes to politics is the lack of identification between them and the authorities. In this paper we present how the youth segment is represented across the world's parliaments, which are the countries encouraging most the youth to get involved in politics and where young people can easily become a member of the parliament.
\end{abstract}

Keywords: youth, political participation, member of the parliament, representation

\section{Introduction}

Youth political behaviour and participation has been a popular theme among researchers in the last decades. Questions like How active is youth in the political arena? Have political behaviours changed over the last past years? Is youth political participation in decline or we attend a change of implication? are still researched by scientists who focus on finding possible explanations and causes to these topics. More and more comes into discussion the idea that conventional participation becomes less appealing at least for the youth segment. Loss of community ties, little interest in and knowledge of political processes, low levels of trust in politicians and growing cynicism of democratic institutions are often seen as indicators of the younger generations' weakened sense of citizenship and political engagement (Pirie and Worcester, 1998; Haste and Hogan, 2006; Dalton 2008; Stoker, 2006; YCC, 2009 in Mycock and Tonge, 2012).

One major idea that explains the lack of interest of the youth segment for politics is the gap between them and the political representatives, the parliamentarians failing in fighting for the young people's needs. Even if it has been agreed that no two parliaments are the same, starting from the form, the structure, the number of members, the way of functioning or the role, in the end all parliaments share the same ambition: to give people a voice in the management of public affairs. ${ }^{1}$ But how can parliaments give young people a voice if there is no connection between these two segments? How can parliaments best represent the youth segment if there is a lack of identity and a low level of trust in politicians? And more important: why should parliaments encourage young people to participate?

The importance of the presence of young people in elected positions is sustained by demographic figures which emphasize the population's distribution in terms of age : the median age of the world's population (28.5 according to UNDESA, 2013) and the high percentge (49\%) of the voting age population are between the ages of 20 and 39 (UNDESA, 2013).

As the discussion is focused on youth and parliamentarians, we would like to start with defining the youth segment so that to have a benchmark when comparing the overall youth segment with the parliamentarians youth segment. Age seems to be the more used variable when defining the youth segment, particularly in relation to education and employment, but in terms of specific ages, all persons between the ages of 15 and 24 years are considered to be part of the yoith segment, according to the UN. ${ }^{2}$ This definition has been first used in 1981 by the Secretary-General of the United Nations in the report to the General Assemblr on International Youth Year. ${ }^{3}$

\footnotetext{
${ }^{1}$ Global Parliamentary Report, The changing nature of parliamentary representation, available at http://www.ipu.org/pdf/publications/gpr2012-full-e.pdf

${ }^{2}$ http://www.unesco.org/new/en/social-and-human-sciences/themes/youth/youth-definition/

${ }^{3}$ Definition of Youth, available at http://www.un.org/esa/socdev/documents/youth/fact-sheets/youth-definition.pdf
} 
On the other hand, while trying to shape the general profile of the parliamentarians some interesting figures came out: $1.65 \%$ of parliamentarians around the world are in their 20 s and $11.87 \%$ are in their $30 \mathrm{~s}$; the average age of parliamentarians globally is 53 (50 years old for women parliamentarians); young people between 15 and 25 constitute a fifth of the world's population; in the area of political participation, in a third of countries, eligibility for national parliament starts at 25 years old or older ${ }^{4}$, thus the numbers can easily explain the existing gap between the two parts. As we can see in the table below, the 20s age range manages to exceed only the 80 s and 90s age ranges, the majority of the members of the parliaments being distributed between two age ranges: the 40s and the 50s. Young people are considered to be an excluded majority (Joshi, 2014), their policy interests being overlooked. Including a higher number of young people in the structure of the parliaments could determine the increase in civic participation and active citizenship, by demonstrating that politics is open for the youth segment as well as it is open for the other segments (Bouza, 2014).

The level of data availablity in terms of the age of parliamentarians is very limited, thus the below analysis aims to provide an overview which could represent the starting point of some more detailed analyses.

TABLE I: Parliamentarians age across the world

\begin{tabular}{ccc}
\hline \hline Age range & Number & $\mathbf{\%}$ \\
\hline $20 \mathrm{~s}$ & 326 & $1.65 \%$ \\
$30 \mathrm{~s}$ & 2,348 & $11.87 \%$ \\
$40 \mathrm{~s}$ & 4,990 & $25.22 \%$ \\
$50 \mathrm{~s}$ & 6,552 & $33.12 \%$ \\
$60 \mathrm{~s}$ & 4,286 & $21.67 \%$ \\
$70 \mathrm{~s}$ & 1,071 & $5.41 \%$ \\
$80 \mathrm{~s}$ & 188 & $0.95 \%$ \\
$90 \mathrm{~s}$ & 21 & $0.11 \%$ \\
Total & $\mathbf{1 9 , 7 8 2}$ & $\mathbf{1 0 0 \%}$ \\
\hline \hline
\end{tabular}

Source: Source: Inter-Parliamentary Union, 2011

If we consider the geographical regions, a significant difference in terms of average age is registered for the sub-Sharan Africa states which have the smallest average age of parliamentarians of only 49 , as compared to the Arab States and Asia, which are situated in the opposite corner with an average age of 55.

The structure of the parliaments represent another important variable as the Upper chambers of the bicameral parliaments are more rigid when it comes to young members: in the unicameral parliaments where the average age is 50 (with a minumum of 20 and a maximum of 90), and the bicameral parliaments where for the Lower chambers we have an average age of 52 (with a minimum of 21 and a maximum of 93) and for the Uppper chambers we have an average age of 59 (with a minimum of 28 and a maximum of 95).

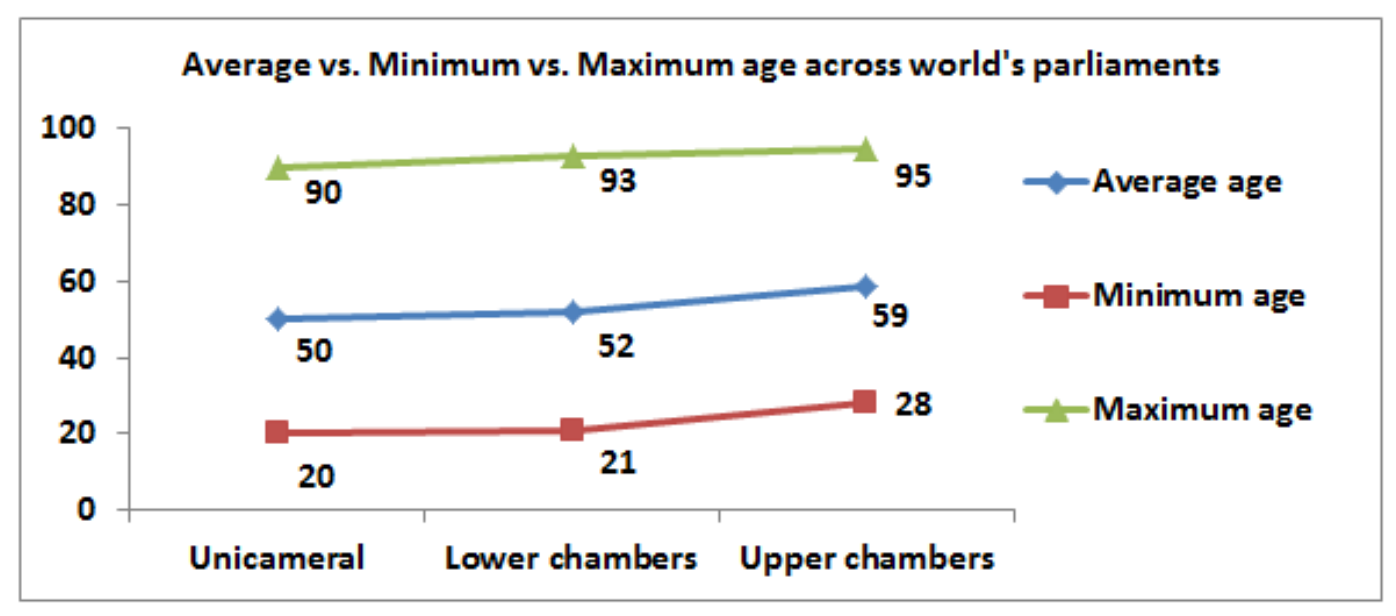

Fig. 1: Average vs. Minimum vs. Maximum age across world's parliaments Source: Source: Inter-Parliamentary Union, 2011

\footnotetext{
${ }^{4}$ http://www.un.org/esa/socdev/documents/youth/fact-sheets/youth-political-participation.pdf
} 
At an European level, the average age of parliamentarians is 53, with Malta and Ukraine registering the most interesting figures. If we consider the youngest and the oldest members of the parliament, we have to mention that Sweden has a MP of only 19 years and UK has a MP of 98 years.

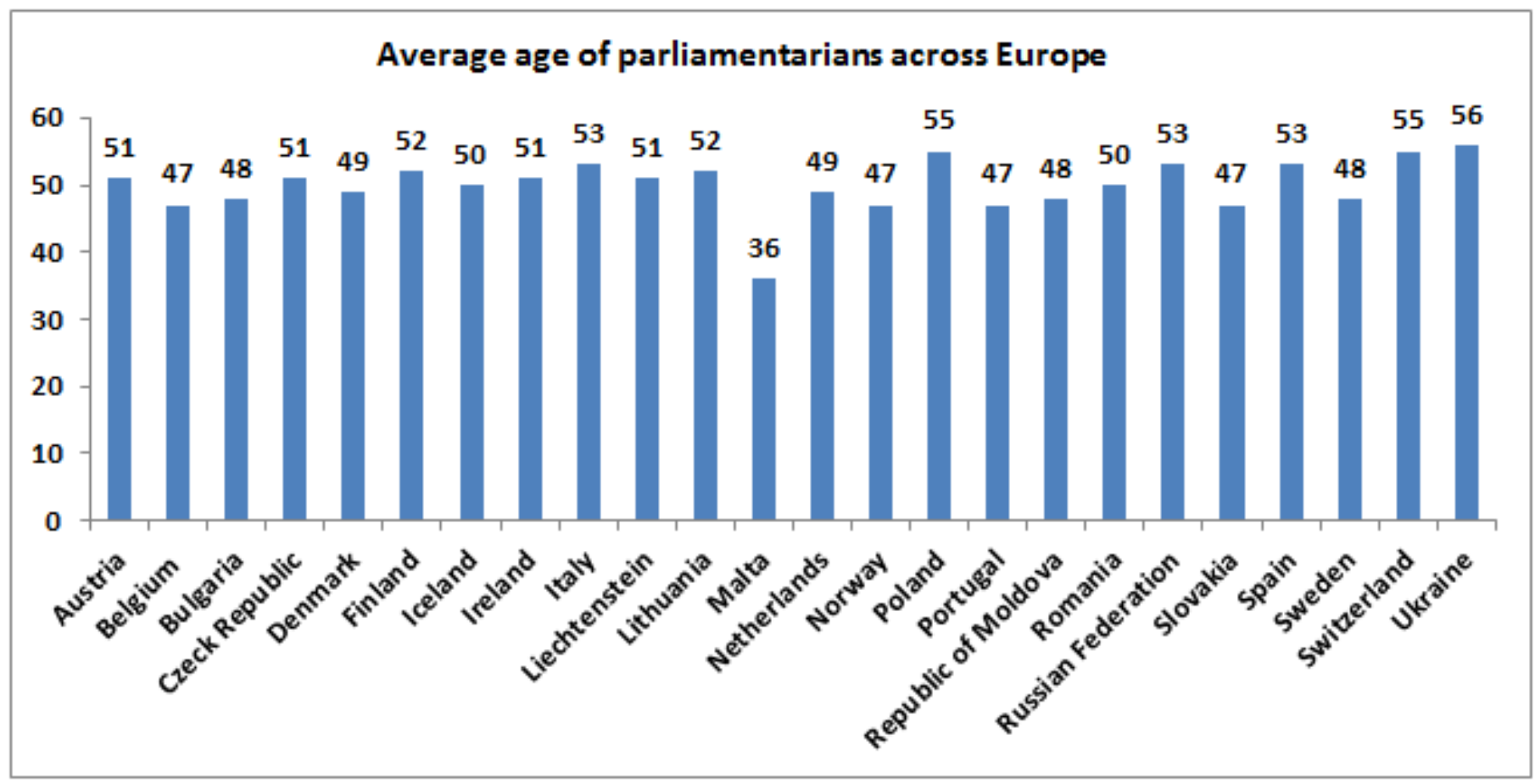

Fig. 2: Average age of European parliamentarians

Source: Source: Inter-Parliamentary Union, 2011

The above chart becomes more interesting if we take into consideration the definition of the youth segment offered by the United Nations (which cannot be used in the parliamentarians context as we saw already due to the average age and to the common practice) and the definition used by the Inter-Parliamentary Union which applies the 45 years threshold for defining a member as young. By using different thresholds (30, 40 and 45), three different rankings can be differentiated:

- „When "young” is defined as under 30, only one country, Norway, breaks the 10 per cent barrier. Two thirds of single and lower houses of parliament have 2 per cent or fewer young parliamentarians. All upper houses have less than 6 per cent, with three quarters electing no young parliamentarians at all.

- When "young" is defined as under 40, the proportion of young parliamentarians increases slightly. Leading countries are San Marino and Denmark for single and lower chambers, and Kenya and Belgium for upper houses. About half of all single and lower chambers have between 10 and 20 per cent young legislators. Upper houses fare less well, with the vast majority scoring below 10 per cent.

- When "young" is defined as under 45, some States show substantial progress, most notably the Netherlands with more than 60 per cent young parliamentarians in the lower house. Indeed, more than one third of the single and lower chambers examined in the report had more than 30 per cent young people in parliament. Upper houses perform less well, however, with the top countries, like Belgium and Kenya, electing only half as many young representatives."

The table below presents the top 20 countries with parliamentarians under 30 years:

\footnotetext{
${ }^{5}$ Inter-Parliamentary Union, Youth participation in national parliaments, available at: http://www.ipu.org/pdf/publications/youth_en.pdf
} 
TABLE II: Top 20 countries with higher $\%$ of MPs under 30 years

\begin{tabular}{ccc}
\hline \hline Rank & $\%$ & Country \\
\hline 1 & 10.1 & Norway \\
2 & 9.0 & Denmark \\
3 & 6.0 & Cuba \\
4 & 5.8 & Chile \\
5 & 5.6 & Slovenia \\
6 & 4.8 & Serbia \\
7 & 4.7 & Canada \\
8 & 4.4 & Austria \\
9 & 3.7 & Sweden \\
10 & 3.6 & Andorra \\
11 & 3.3 & Luxembourg \\
12 & 3.2 & Iceland \\
13 & 3.0 & Zimbabwe \\
14 & 2.9 & Indonesia \\
16 & 2.8 & South Africa \\
17 & 2.6 & Germany \\
18 & 2.5 & Paraguay \\
19 & 2.4 & Bosnia and Herzegovina \\
20 & 2.2 & India \\
\hline \hline
\end{tabular}

Source: Source: Inter-Parliamentary Union, 2011

While voting is considered to be the key political right and form of participation, recent discussions and debates have emphasized the importance of the equal access to decision making positions, thus alternative forms of participation needs to be considered. As it has already been proved that the youth segment is more likely to embrace new forms of participation, the lack of identification with the political representatives will remain a major issue for the legitimacy degree of the members of the parliament as long as the age discrepancies between the two groups remain as high as we presented above.

\section{References}

[1] Bouza, Luis. 2014, Addressing youth absenteism in European elections. Stockholm: International IDEA and European Youth Forum

[2] Dalton, R.J., 2008, Citizenship Norms and the Expansion of Political Participation. Political Studies, 56 (1), pp.76-98 http://dx.doi.org/10.1111/j.1467-9248.2007.00718.x

[3] Definition of Youth, available at http://www.un.org/esa/socdev/documents/youth/fact-sheets/youth-definition.pdf

[4] Global Parliamentary Report, The changing nature of parliamentary representation, available at http://www.ipu.org/pdf/publications/gpr2012-full-e.pdf

[5] Haste, H. and Hogan, A., 2006. Beyond conventional civic participation, beyond the moral-political divide: young people and contemporary debates about citizenship. Journal of Moral Education, 35(4), pp. 473-493. http://dx.doi.org/10.1080/03057240601012238

[6] Inter-Parliamentary Union, Youth participation in national parliaments, available at: http://www.ipu.org/pdf/publications/youth_en.pdf

[7] Joshi, Devin, K. 2014, The inclusion of younger age cohorts in Asian parliaments: Do electoral systems make a difference?, Representation 49 (1): 1-16 http://dx.doi.org/10.1080/00344893.2013.775960

[8] Pirie, M. and Worcester, R.M., 1998. The Millennium Generation. London: Adam Smith Institute.

[9] Stoker, G., 2006. Explaining Political Disenchantment: Finding Pathways to Democratic Renewal. The Political Quarterly, 77(2), pp.184-194.

http://dx.doi.org/10.1111/j.1467-923X.2006.00761.x

[10] UNDESA. 2013. World population prospects: The 2012 revision. New York: United Nations Office of Development and Social Affairs.

[11] YCC (Youth Citizenship Commission), 2009. Old Enough to Make a Mark? Should the Voting Age be Lowered to $16 ?$ Making the Connection? Building Youth Citizenship in the UK. London: YCC. 
International Conference on Studies in Humanities and Social Sciences (SHSS-2015) Nov. 25-26, 2015 Paris (France)

[12] http://www.unesco.org/new/en/social-and-human-sciences/themes/youth/youth-definition/ [13] http://www.un.org/esa/socdev/documents/youth/fact-sheets/youth-political-participation.pdf 